\section{Birlesik Dünya Arastrma Cypriot Journal of Educational BD-CENTER \\ Sciences}

Innovasyon ve Yayıneılık Merkezi
Volume 15, Issue 4, (2020) $634-650$

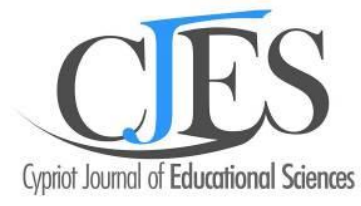

www.cjes.eu

\title{
Analysis of study skills employed by Ghanaian high school science students
}

Godwin Kwame Aboagye a, University of Cape Coast, College of Education Studies, Faculty of Science and Technology Education, Department of Science Education, Cape Coast, Ghana, https://orcid.org/0000$\underline{0002-2268-8649}$

Kwaku Darko Amponsah b*, University of Ghana, Department of Teacher Education, P. O. Box LG 1181, Legon, Accra, Ghana, https://orcid.org/0000-0002-7824-6516

Eugene Adjei Johnson ', University of Cape Coast, College of Education Studies, Faculty of Science and Technology Education, Department of Science Education, Cape Coast, Ghana, https://orcid.org/0000$\underline{0003-2858-2199}$

\section{Suggested Citation:}

Aboagye, G. K., Amponsah, K. D. \& Johnson, E. A., (2020). Analysis of study skills employed by Ghanaian high school science students. Cypriot Journal of Educational Sciences. 15(4), 634 - 650. DOI:

$10.18844 /$ cjes.v\%vi\%i.5047

Received October 5, 2019; revised February 1, 2020; accepted August 3, 2020.

${ }^{\circ} 2020$ Birlesik Dunya Yenilik Arastirma ve Yayincilik Merkezi. All rights reserved

\begin{abstract}
This study was motivated by the desire to explore the study skills employed by science students in senior high schools (SHS) in the Cape Coast metropolis across the Central Region of Ghana. A total of 600 SHS second-year science students, 354 males, and 244 females, took part in the investigation. The study adopted a cross-sectional survey design. The "Study Skills Scale" questionnaire was utilised for data collection to determine the kind of study skills employed by the science students, across gender, age range, and school-type. The arithmetic mean was used to establish the degree to which students employ study skills strategies in their learning. Similarly, the consequence of gender, age range, and school-type on the eight subscales of study skills strategies was determined using a one-way multivariate examination of variance. Findings from the investigation indicated that SHS science learners employ study skills strategies in their learning to a large extent for all the subscales of study skills strategies. However, female students employ the memory and concentration study skills strategies more effectively than their male counterparts; demographic variables, such as age range and school-type, do not influence students' study skills significantly. The implications for this study for policy and practice were discussed.
\end{abstract}

Keywords: Academic performance, age range, gender, school-type, study skills, senior high school science students.

\footnotetext{
* ADDRESS FOR CORRESPONDENCE: Kwaku Darko Amponsah, Department of Teacher Education, P. O. Box LG 1181, University of Ghana, Legon, Accra, Ghana.

E-mail address: kdamponsah@ug.edu.gh / Tel: +233 550692191
} 


\section{Introduction}

Senior high schools (SHS) in Ghana are grouped as category A, B, C, or D schools based on several factors, including academic achievement. Recently, civil societies in Ghana have indicated that the scholarly performance of SHS' students in Ghana has declined, giving so many reasons for that effect and proffering solutions to salvage the situation. Accordingly, the Institute of Statistical, Social and Economic Research (2015) indicated that there is a decline in the excellence of education at the various levels of the academic stream. It was observed that although there has been increased access to education over the years, it is not matched by increased funding. It seems many students lose the opportunity to attain tertiary education due to a missing link in the educational system in Ghana, especially SHS, which some people presume is in crisis. Institute of Statistical, Social, and Economic Research (2015) opined that "Early Grade Mathematics Assessments" and "Early Grade Reading Assessments" administered in 2013 indicated that after primary two, the majority of the pupils' sampled were unable to read. This trend is very disturbing as it has the potential of being carried over to the junior high school (JHS) and SHS. It is, therefore, not surprising that students' academic attainment, particularly in Mathematics and Science at the West African Senior School Certificate Examination (WASSCE), is experiencing a decrease which became evident after the 2012 WASSCE. This is worrying because according to the Institute of Statistical, Social and Economic Research (2015), it is supposed to peak, as there have been increases in high school students' enrolments with a corresponding increase in the number of high school teachers recruited. In view of this, it is believed that educational outcomes can be improved in several ways, but most importantly, an aspect that has been overlooked, but which could be a remedy involves giving assistance to students to enable them to regulate the way they learn. This can be done through the effectual use of learning techniques, which are termed as study skills. This claim was confirmed by Bulent, Hakan, and Aydin (2015) who alluded to the fact that the singular most important reason accounting for student's failure is the deficiency in skills and attitude towards studies. Naqvi, Chikwa, Menon, and Al Kharusi (2018) further claim that psychologists singled out study skills as the most contributory factor to student's performance since it helps students to manage their time judiciously, use effective engagement strategies and connect the basis for studying to their lifelong goals.

Learning skills are a group of proficiencies that are concerned with organising and assimilating novel material, keeping the information that has been taken, or the act of assessment (Bremer, 2015). Some of these proficiencies include mnemonics, which help with keeping lists of information, concentration procedures, and efficient reading and effective note taking. These skills are usually crucial to academic accomplishment in school and they are regarded as important for obtaining respectable grades, and beneficial to lifelong learning of the individual (Bremer, 2015). This suggests that study skills comprise a variety of combined neural structures that augment the effectiveness and learners' ability to accept, keep, and process facts. Considering the preceding, learning abilities could be viewed through double unmistakable, similarly significant features related to scholarly together with non-scholastic procedures (Crede \& Kuncel, 2008). Awang and Sinnadurai (2011) have indicated that academic aspects of study skills include but not limited to information processing, memory techniques, metacognitive understanding, and organisational and time-management procedures. Similarly, nonacademic aspects of study skills incorporate the outlook of fruitful learning, such as determination, inspiration, self-viability, and craving for development and enhancement (Putwain, Sander \& Larkin, 2013). In a research conducted by Bandura (1986) on self-efficacy, it was observed that attitude is a more grounded indicator of progress than capability in a subject and can be conveyed to and developed in learners. From the foregoing, it can be argued that the characteristics of learning abilities 
should be assessed as well as estimated by considering these two viewpoints: (1) factors, for example, study techniques and propensities and (2) factors, for example, mentality and self-adequacy.

Accordingly, Nagaraju (2004), opined that utilising the brain to solve an issue or question, which is an aspect of learning and an examination of a specific topic is referred to as study. It was indicated that learning skills are usually crucial to accomplishment in school as they are the methodologies used to assist learners to learn. Consequently, learning skills are thought about as indispensable for obtaining decent grades, and helpful for learning for an incredible duration. Study skills may handle the way of sorting out and taking new information or managing assessments (Nagaraju, 2004). Some of these proficiencies include mnemonics, which help with keeping lists of information, concentration procedures, efficient reading as well as competent note taking. Typically, study skills are characterised as learners' capacity in time management and having different support systems to finish scholarly work effectively (Ozsoy, Memis, \& Temur, 2009). With regard to scholarly achievement, Bashir and Matto (2012) characterised the scholastic achievement as the proportion of how much know-how the individual has gained from school or teaching. Similarly, study skills are the number and sorts of study schedules, which a learner uses during a standard time of study that happened in a favourable learning atmosphere (Ozsoy, Memis, \& Temur, 2009). This suggests that there will be a positive impact on students' study skills if they persistently study in a congenial environment and in an orderly manner. It is, therefore, essential for investigators to build up causal associations between identifiable study methods and viable learning embraced by the learners to eventually improve their scholarly achievement. Based on the above discussion, there is a surge in the number of research studies regarding study skills because its utilisation is very firmly connected with scholastic accomplishment.

A classroom setting is a perfect atmosphere in which study skills can be taught, as they form a part of the curriculum from primary school to the secondary school level. In any case, a look into previous research materials demonstrates the absence of preparation in learning expertise and tendencies amid instructors of state-funded institutions (Cornick, Guy, \& Beckford, 2014). Despite the way that the research affirms by and large upgrades in scholarly accomplishment when learners apply great study skills, it has been observed that curriculum for offering students with precise study procedures does not exist as mandatory and is infrequently available within US schools (Demir, Kilinc, \& Dogan, 2012). Teachers within primary and secondary schools (i.e., since these are the formative stages students' academic life) ought to teach study strategies, which would be then transformed into study inclinations and in the long run to improve student inspiration, self-viability, and scholarly accomplishment as they move from lower to upper grades. A study was conducted among middle school teachers on study skills and the report uncovered that educators did not teach these skills in the classroom as they had limited know-how of study skills (Thorpe, 2010). Further researches conducted by Smith, Groves, Bowd, and Barber (2012) as well as Shetty and Srinivasan (2014) have shown that focused study skills programme is more effective and produces positive results when introduced at the lower level of the academic ladder than at higher education. A research conducted by Renzulli (2015) revealed that university students on scholastic probation lacked the study skills strategies that were expected to enable them to finish their tertiary programmes. The research has shown that when students with different abilities apply study skills strategies across numerous subject areas, their academic achievement is fundamentally enhanced (Awang \& Sinnadurai, 2011). Similarly, grade point average (GPA) has been seen to increase across gender, socioeconomic status, and different academic areas so long as there is an effective use of study skills strategies (Al-Hilawani, 2016). Consequently, Yadav, Ansari, and Savant (2000) opined that it is evident that for students to develop optimum knowledge and perceptual capabilities, they should adopt stringent study skills strategies. This suggests that learners need to be guided to utilise relevant studying strategies in order for them to have the capability for appropriate concepts development. Thus, the achievement of 
learners, using study skills strategies, will be enhanced as a result of the ease with which most concepts can be learned. This argument is supported by Ogbodo (2010) who is of the view that achievement of learning goals depends on the utilisation of appropriate study skills strategies since learners engage in a prescribed pattern of study behaviour. Ogbodo opined that there is a universal perception that suggests that most learners are grumbling that they do not attain better grades, which could be attributed to poor study skills of students, as well as the improper attitudes exhibited by learners regarding study as the development of good study habits are barely considered. Crow (1968) demonstrated that learning includes the improvement of legitimate study propensities and abilities yet seen that the issue of study skills is one of the widespread significant issues both from a theoretical and practical perspective.

\subsection{Statement of the problem}

The studies reviewed so far have revealed that study skills are vital to learners' academic accomplishment (i.e., educational excellence, students' intelligence, and their affective features). Research has indicated that even though there is an abundance of interactive tools and pedagogic methods than ever before, the study habits of students in the 21st century has not received the attention that it deserves at the high school level (Entress \& Wagner, 2014; Feurerstein \& Falik, 2010; Ogbodo, 2010). Again, students are not able to manage their time for effective learning, organise their notes for effective studies and focus on main ideas while reading because there has been little or no emphasis on study skills (Cornick et al., 2014; Demir et al., 2012; Thorpe, 2010). Even though various research studies have been directed on study skills at various levels of education, there appear to be very limited studies available which assessed all eight subscales of study skills. Motivation, time management and test preparation, and test anxiety are three study skills strategies investigated by Bulent et al. (2015) for undergraduate students. The study found the mean scores of the three factors measured to be quite high. Their results also found there was no substantial variation among boys and girls regarding motivation, quiz preparation as well as test anxiety but found the mean scores of female undergraduate' time management to be high. Research studies have shown that different students have unique skills and that what may be good study skills for one individual may not be good for another (Ebele \& Olufu, 2017). Also, variations in student attributes, such as age and gender, and type of educational setting, such as school-type, can influence how study skills are effectually used (Dunlosky, Rawson, Marsh, Nathan, \& Willingham 2013). Consequently, Dunlosky et al. observed that older students, for instance, may benefit more when introduced to good study skills than younger ones since their basic cognitive abilities may influence their easy accommodation such study strategies. Although studies have been conducted on the variables, such as age and school-type affect students' performance, learning styles and other variables, their effect on study skills has not been sufficiently explored. Accordingly, the motivation behind this research was to discover the current study skills strategies SHS science students employ in learning science based on the demographic variables (age, gender, and school type) in the Central Region of Ghana. The investigation was guided by one research question and three hypotheses. A 0.05 level of significance was used to test the hypotheses.

\subsection{Research Question}

1. To what degree do senior high school science students use study skills strategies in their learning? 


\subsection{Hypotheses}

1. There is no statistically significant difference in the study skills strategies employed by SHS science students in learning across gender.

2. There is no statistically significant difference in the study skills strategies employed by SHS science students in learning across school-type.

3. There is no statistically significant distinction in study skills approaches employed by SHS science students in learning across age range.

\section{Literature review}

The focus of this study concentrated on eight study skills strategies often reported in the literature as the most useful strategies that promote students' learning. The literature reviewed on the eight strategies used is presented.

\subsection{Time management and procrastination}

Claessens, van Eerde, Rutte, and Roe (2007) describe time management as an array of procedures for managing, and scheduling together with proper usage of time. In addition, it is the process of scheduling and showing awareness of the amount of time it takes to explicitly exercise, principally to build capability, competence together with output. It's made up of the different requests normally made upon an individual concerning work, social life, family, pastimes, specific interests of people and responsibilities in relation to the end of time. The efficient use of time allows the individual to decide on spending/overseeing activities at a time convenient to them (Cottrell, 2013). It is a strategy for effective time use in accomplishing several tasks. Having enough time often to accomplish tasks, individuals usually postpone action to the last minute (i.e., procrastination). Steel (2007) has observed that the adjournment is made up of the determined postponement of a scheduled strategy, regardless of being conscious of negative results. Academic procrastination is termed as postponing scholarly responsibilities, of which some examples are, getting ready for examination and carrying out one's take home assignment to the end and to experience uneasiness resulting from this action (Capan, 2010). Similarly, Van Eerde (2003) conducted research on academic procrastination and found that academic procrastination and academic achievement have a moderate to a strong negative association.

\subsection{Memory and concentration}

An essential obstruction to educational accomplishment is the challenge of defending the pursuit of educational objectives emanating from undesirable interferences. Some of the undesirable interferences include but not limited to focusing in a classroom setting, finishing take home tasks, reading, and focusing during a quiz (Parks-Stamm, Gollwitzer, \& Oettingen, 2010). One needs to process information in a friendly atmosphere (concentration) in order to avoid such impediments and be able to process and retain task-relevant information or working memory (Fougnie, 2008). Baddeley (2000) opined that working memory as indicated by one widely utilised model is also accountable for controlling attention and the process which is included in an array of regulative activities, as well as the recovery of information from long-term memory. Additionally, operational memory comprises numerous parts whose activities are coordinated, and which is accountable for the provisional stockpiling and handling of data (Alloway \& Alloway, 2010).

\subsection{Test strategies and test anxiety}

Researchers, instructors, and counsellors have been worried over the years with their lack of understanding of students' emotional experiences, such as test anxiety, during the testing process. 
This is because they believe that test anxiety might have a devastating effect on achievement in an exam, scholastic accomplishment, and overall well-being of the student (Bonaccio \& Reeve, 2010). Hunsley (1985) found that test anxiety is positively correlated to poor test performance when taken either at the commencement or at the completion of the semester. However, Chapell, Blanding and Silverstein (2005) observed the rather substantial opposite correlation between test apprehension and learners' GPA. The findings revealed that the results (average of a $\mathrm{B}+$ ) of tertiary students with lowtest- apprehension were better than the results (average of a B) of those with high-testapprehension. This goes on to prove that test apprehension plays a crucial part in student learning and achievement.

\subsection{Study aids and note-taking}

Researchers continue to conduct research on the approach used by students to review notes on the improvement of the process of taking and reviewing notes as university students need these skills to have a meaningful learning experience (Grabe, 2005). Accordingly, Kobayashi (2005) observed that undergraduates are of the view that copying notes ensures one paying attention to the lecture notes, understanding of the lecture notes to be well-read, and the consequent remembrance of information. Unfortunately, some individuals are of the view that notetaking alone has the propensity of facilitating the act of comprehending and systematising the learning material. Slotte and Lonka, (1999) indicated that these categories of people are those who summarised their lecture notes knowing very well that such summaries are irrelevant as they could not possibly use them later. The findings in another study revealed that the instruction on note-taking strategy had a substantial influence on learners' academic accomplishment (Haghverdi, Biria, \& Karimi, 2010), which agrees with the view that scholastic excellence correlates positively with effective notetaking.

\subsection{Reading and selecting main ideas}

Research has shown that reading comprehension is a multifaceted intellectual capacity that needs the ability to incorporate written information into the knowledge base of learners, which results in the amplification of rational illustration (Meneghetti, Carretti, \& De Beni, 2006). This suggests that the motivation for reading is to try to understand what the author seeks to communicate. This can be done by going through two layers of reality: invisible and visible layers (Küçükoğlu, 2013). Therefore, the goal of reading is to make what we cannot see visibly clear (Kose, 2006). Thus, people become lopsided and seize to spark if they relinquish their reading habits. To avoid this obstacle, teachers should teach reading strategies to help improve students' comprehension (Kucukoglu, 2013). Similarly, Block and Israel (2005) opined that the development of generic skills, such as the capability to anticipate, make associations, visualise, infer, question, and summarise are approaches that have been shown to enhance reading comprehension. The majority of people believe that early effective reading is likely to promote a progressive life-course bearing, encouraging incredible academic and psychosocial outcomes, though hindered reading capabilities are likely to provoke fewer charming outcomes (Kern \& Friedman, 2009). It implies that reading exercises are assigned to students to aid their comprehension of scholastic materials and to identify the interrelationship among concepts. Cogmen and Saracaloglu (2009) indicated that reading comprehension approaches can be beneficial in the sense that, it aids readers to recollect important facts, determine which information is useful or not, consider the key idea, and make a comment on the issue under discussion.

\subsection{Motivation and attitude}

Motivation has been defined as the usual positive force by Osa-Edoh and Aluta (2012) which determines why people achieve their capabilities and perform good works. Nagaraju (2004) stated that motivation is a condition of a creature, which includes the presence of a necessity that drives the creature from inside and guides its undertakings to an objective that can achieve the fulfillment of the 
necessity. This implies that motivation alludes to whatever is inside a person that pushes the person into activity without influence from other individuals or circumstances. Motivation makes individuals develop the strength to accomplish a task without taking inspiration from external sources (Ncube \& Zondo, 2018). Intrinsic and extrinsic motivations are the two types of motivation used by learners in the course of their studies. Intrinsic motivation refers to attaining something since it is inherently captivating or appealing, whereas extrinsic motivation makes reference to achieving something since it gives rise to a distinguishable consequence (Mizuno et al., 2008). In effect, one needs either of the two motivations or both to muster courage in order to accomplish a task or purpose. It is, therefore, not surprising for Komarraju, Karau and Schmeck (2009) to contend that scholarly achievement is unequivocally influenced by individual differences in motivation.

Attitude is a pattern of beliefs established over a period in a given socio-cultural setting. These beliefs play a vital part in the learning process. There is a general agreement that a positive attitude establishes the framework for learning and vice versa (Bain, McCallum, Bell, Cochran, \& Sawyer, 2010). Students who are motivated or de-motivated have different perceptions about their educator, the class they belong to, and the curriculum that they use. These perceptions form the foundation of attitudes that students have towards learning.

\subsection{Organising and processing information}

It has been observed that the educational difficulties encountered by many learners are as a result of the absence of personal organisation together with discipline rather than a lack of intellectual ability. Accordingly, Komarraju et al. (2009) indicated that disciplined and ordered learners stand a better chance of being inspired compared to their counterparts who are unmanageable and clumsy. In addition, a significant issue in scholastic achievement is information processing. Surface-level processing and deep level processing are two methods used by learners in processing information. Whereas surface-level processing consists of information processing approaches like (e.g. analysing, memorising, and repetition), deep level processing encompasses information processing approaches such as (e.g. relating, structuring and critical thinking) (Rozendaal, Minnaert, \& Boekaerts, 2003). Even though both methods reveal some form of regulation rooted in them, learners who continuously memorise the lecturers' notes are reliant on a system of outside guidelines. However, learners who make use of critical thinking ability to process knowledge laterally together with writers, lecturers together with learners alike, validating the consistency of instructions given by the teacher show resourcefulness and are likely to be more regulating itself without intervention from external bodies (Vermunt \& Verloop, 2000). It implies that the proper processing of information leads to greater learning outcomes.

\subsection{Writing skills}

Writing is an intricate, complicated, and decisive act of correspondence, achieved in diverse settings, under numerous time constraints, and with a diversity of language resources and high-tech tools (NAEP, 2011). This suggests that all exercises related to the assessment for writing should specify its exact purpose, and the specific audience writing should address (NAEP, 2011). In most countries' educational systems, the evaluation of literacy skills and broad educational accomplishment through structured essay-type examination is being utilised frequently and exponentially in many subject areas (Brown, 2010). The rationale for this is that this approach has offered a better way of recording final scores and subject selection. Consequently, writing skill is an uncommon capacity that permits essayists to communicate their reflections as important words and of a psychological collaboration through composed messages (Jani \& Mellinger, 2015; Knoch, May, Macqueen, Pill, \& Storc, 2016). Writing skills can assist students in improving their independence, eloquence, and ingenuity in writing. Students will also become better communicators in various ways when they master these skills as it makes others to comprehend their ideas in a better way. 


\section{Conceptual Framework}

This investigation was based on the assertion that demographic variables, such as gender, age variations together with the type of school students attend, can influence the study skills strategies and the utilisation in learning science which can improve students' performance. The conceptual model for this study is represented in Figure 1.

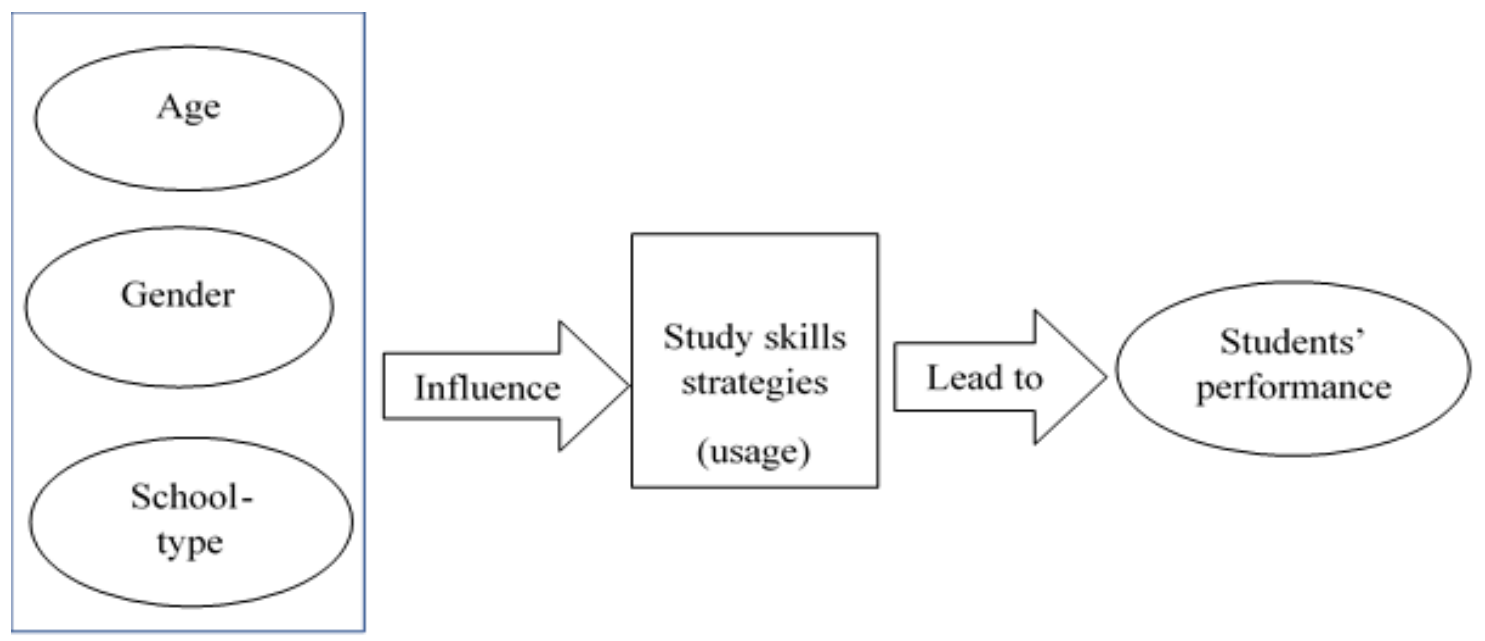

Figure 1. Model of the conceptual framework

The study has shown that gender plays a critical role in the way learners assimilate knowledge. A significant proportion of the literature pointed out the fact that female learners exhibit impressive study skills comparatively to their male counterparts simply because they take down notes carefully, pay attention, have the ability to recall information obtained from lectures, spend more time on assignments and tasks, more serious on managing their time efficiently and setting goals and planning (Bulent et al., 2015; Naqvi et al., 2018). However, a few studies also reported that male students possess great thinking and analytical skills than female students (Gledhill \& Van der Merwe, 1989). This shows that gender has a serious influence on how students adopt study skills in their learning.

Despite no literature, after the extensive search, was found on how age difference and school-type influence the students using study skills in their learning, research studies maintain that no matter the age or academic level (Ashish, 2013), programme of the study and the areas of specialisation (Bulent, 2015; Helfand, 2017) and level of study (Papa et al., 2016; Sekar \& Rajendran, 2015), students differ in the type of study skills they employ in learning. We can use this evidence as a proxy to assume that students can differ in the way they use study skills across school-type. It can be concluded that demographic variables, such as gender, age range, and school-type have the tendency of influencing the type of study skills strategies students are likely to use in learning.

The key assumptions that most researchers (Demir et al., 2012; Kumar, Kulkami, Kavitha, \& Manjunath, 2016) have made were that when students possess effective study skills, they are likely to perform creditably academically. This means there is a positive significant relationship between study skills together with students' achievements (Demir et al., 2012; Ogbodo, 2010). Adeninyi (2011) further upholds the view that employing worthy study skills in learning provides learners with the opportunity to perform and aspire for higher education careers. It is for this reason that the current study was conducted. 


\section{Methods}

\subsection{Research Design}

This study adopted the cross-sectional survey design since the aim of the study was to investigate the study skills science students at the SHS level use in learning. This design was the most appropriate because it has the potential of gathering standardised information on study skills using the same instruments and questions for all participants and can also be used to ascertain cause and effect relationships across variables being measured (Cohen, Manion, \& Morrison, 2007; Creswell, 2012).

\subsection{Sampling procedure}

A total of 600 SHS 3 students randomly sampled from 6 out of the 10 SHS offering the General Science programme in the Cape Coast Metropolis in the Central Region of Ghana took part in this study. Out of the 10 SHS, there are only two girls, only three boys, and five mixed schools. Two schools out of each category were sampled to participate in this study. The computer-generated random numbers were then used to sample 100 SHS 3 science students from each school for the study. Table 1 presents the distribution of the sample with respect to gender, school-type, and age range.

Table 1: Distribution of the sample across gender, school-type and age range

\begin{tabular}{lll}
\hline Variable & $\mathrm{N}=600$ & $\mathrm{~N}(\%)$ \\
\hline Gender & Males & $356(59.3)$ \\
School-type & Females & $244(40.7)$ \\
& Boys only & $200(33.3)$ \\
Girls only & $200(33.3)$ \\
Age range & Mixed & $200(33.3)$ \\
& $12-14$ & $10(1.7)$ \\
$15-17$ & $513(85.5)$ \\
& $18-20$ & $77(12.8)$ \\
\hline
\end{tabular}




\subsection{Instrumentation}

In order to determine the study skills strategies employed by the students in Ghanaian SHS, the "Study Skills Assessment Questionnaire" developed by the University of Houston Clear Lake's Counselling Services was adopted. This instrument consists of 64 items designed to measure eight subscales of study skills, namely: Concentration and Memory, Motivation and Attitude, Organising and Processing Information, Reading and Selecting the Main Idea, Study Aids and Note-Taking, Test Strategies and Test Anxiety, Time Management and Procrastination, and Writing skills. Each subscale also consists of eight items. Items on the questionnaire were scored on a four-point Likert-type scale format starting from: $1=$ Never $2=$ Sometimes $3=$ Usually to $4=$ Always. To ensure that the items on the instrument were valid to measure the study skills of SHS in the Ghanaian context, it was pilot tested with 100 students in one SHS in Sekondi-Takoradi Metropolis in Western Region of Ghana. The reliability coefficient calculated using the Cronbach alpha correlation was 0.89 . This coefficient indicates that the items were internally consistent.

The interpretations used by Cottrell (2005) and Maltepe (2016) in their studies to ascertain the extent to which learners utilise study skills strategies in their learning were adopted. The total scores obtained by the students on the entire instrument were analysed by converting them into standard scores. Scores between 64 and 128 were considered as low, moderate if it is between 129 and 192, high if it is between 193 and 256 and very high if the scores are over 256 .

\subsection{Data collection procedure}

Permission was sought from the school authorities and the teachers available during the period of data gathering in order to undertake the study. Regarding each class, the sampled students were educated on the purpose of the study and procedure for responding to items on the questionnaire. Students were urged to think critically about each item carefully by taking a decision. It took students about 50 minutes to finish responding to the questionnaire.

\subsection{Data processing and analysis}

Descriptive statistics, specifically, means, standard deviations and standard scores were utilised to address research question one from the data obtained. This was on the grounds that the research question sought to research the degree to which learners utilise the eight study skills methodologies concerning their learning. The three null hypotheses were tested using a one-way between group multivariate analysis of variance (MANOVA). The plan was to test whether learners vary regarding the eight sub-constructs of study skills across gender, school-type, and age range.

\section{Results and discussion}

\subsection{The extent to which senior high school science students use study skills strategies in their learning}

In this study, the extent to which SHS science students employ study skills strategies in their learning was sought. To get an answer to this question, the data were analysed descriptively, and the findings presented in Table 2.

As indicated earlier, students will have a low study skill ability if the score is between 64 and 128, moderate if it is between 129 and 192, high if it is between 193 and 256 and very high if over 256 (Cottrell, 2005; Maltepe, 2016). Based on these criteria, it was deduced that SHS science students employ study skills strategies in their learning to a high extent for all the subscales. This finding indicates that students devise extra means to study outside the classroom. The fact is that since the SHS science curricula are much loaded, there is a high possibility that should students rely solely on 
what the teachers teach in the normal classroom setting they may not be able to finish the entire curricula.

Table 2: Scores of students using study skills strategies in their learning $(N=600)$

\begin{tabular}{llll}
\hline Study Skills & $\begin{array}{l}\text { Arithmetic } \\
\text { Mean }\end{array}$ & $\begin{array}{l}\text { Standard } \\
\text { Deviation }\end{array}$ & $\begin{array}{l}\text { Standard } \\
\text { Score }\end{array}$ \\
\hline Time management and procrastination & 3.89 & .57 & 248.96 \\
Memory and Concentration & 3.36 & .45 & 215.04 \\
Study aids and note-taking & 3.71 & .61 & 237.44 \\
Testing strategy and test anxiety & 3.49 & .46 & 223.36 \\
Reading and selecting the main idea & 3.83 & .60 & 245.12 \\
Motivation and attitude & 3.88 & .59 & 248.32 \\
Organising and information processing & 3.87 & .55 & 247.68 \\
Writing skills & 3.51 & .65 & 224.64 \\
Total & 3.69 & .40 & 236.16 \\
\hline
\end{tabular}

It is possible that the students engage in other activities, such as personal independent studies, group studies, and extra classes in order to complete the curriculum and be ready for the external final examinations (WASSCE). This suggests that they may be employing these study skills strategies to be in tune with the demands of the educational system. This finding partially confirms the finding of Bulent et al. (2015) that undergraduate schools mean scores in three strategies of study skills (i.e., motivation, time management, and test preparation and test anxiety) to be quite high. The ability of students to utilise a high level of study skills strategies in their learning could have been acquired from their formative school stages.

\subsection{Hypothesis testing}

To test the null hypotheses of no statistically significant differences in the study skills approaches employed by SHS science students in learning across gender, age range, and school-type, a one-way MANOVA was conducted to determine the effect of gender, age range and school-type on the eight sub-strategies of study skills. Preliminary screening of the data showed no violation of all assumptions of MANOVA for homogeneity of covariance matrices, linearity and multicollinearity, multivariate outliers, and multivariate normality, normality, and test of equality of error variance. The descriptive statistics for the gender, age range, and school-type of science students with respect to the study skills strategies are presented in Table 3. As shown in Table 3, it is difficult to find whether the independent variables differ across the various sub-scales of study skills and so further analyses were performed to establish whether there were statistical differences. 
Table 3. Descriptive statistics for gender, age range and school-type with respect to the eight study skills strategies

\begin{tabular}{|c|c|c|c|c|c|c|c|c|c|c|c|c|c|c|c|c|}
\hline \multirow[t]{2}{*}{ 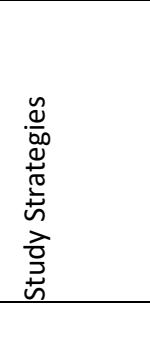 } & \multicolumn{2}{|c|}{ 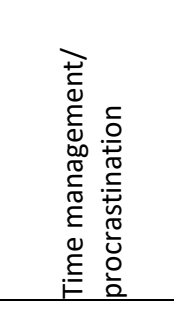 } & \multicolumn{2}{|c|}{ 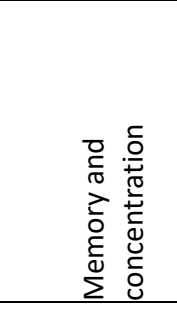 } & \multicolumn{2}{|c|}{ 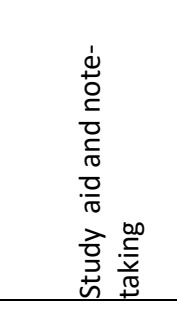 } & \multicolumn{2}{|c|}{ 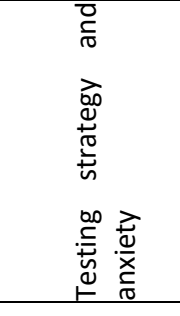 } & \multicolumn{2}{|c|}{ 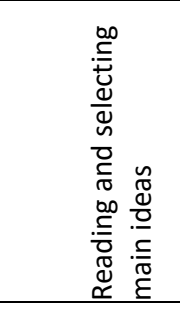 } & \multicolumn{2}{|c|}{ 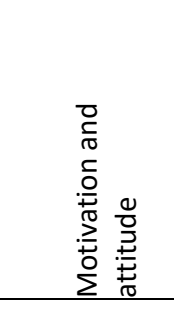 } & \multicolumn{2}{|c|}{ 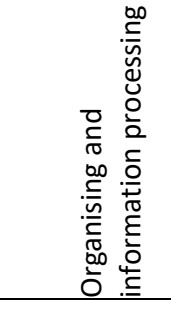 } & \multicolumn{2}{|c|}{ 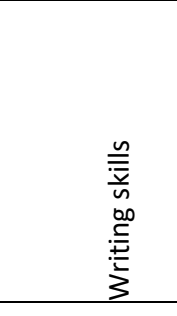 } \\
\hline & $M$ & SD & $M$ & SD & $M$ & SD & $M$ & SD & $M$ & SD & $M$ & SD & $M$ & SD & $M$ & SD \\
\hline \multicolumn{17}{|l|}{ Gender } \\
\hline Male & 3.88 & .54 & 3.31 & .44 & 3.68 & .62 & 3.50 & .47 & 3.82 & .62 & 3.92 & .60 & 3.90 & .54 & 3.52 & .62 \\
\hline Female & 3.89 & .60 & 3.43 & .46 & 3.75 & .60 & 3.47 & .44 & 3.84 & .57 & 3.83 & .58 & 3.83 & .57 & 3.50 & .69 \\
\hline Total & 3.89 & .57 & 3.36 & .45 & 3.71 & .61 & 3.49 & .46 & 3.83 & .60 & 3.88 & .59 & 3.87 & .55 & 3.51 & .65 \\
\hline \multicolumn{17}{|l|}{ Age range } \\
\hline $12-14$ & 3.71 & .60 & 3.19 & .36 & 3.54 & .82 & 3.49 & .44 & 3.92 & .64 & 4.01 & .48 & 3.63 & .70 & 3.26 & 1.02 \\
\hline $15-17$ & 3.88 & .56 & 3.35 & .44 & 3.70 & .62 & 3.49 & .45 & 3.83 & .60 & 3.88 & .58 & 3.87 & .53 & 3.50 & .63 \\
\hline $18-20$ & 3.97 & .62 & 3.46 & .53 & 3.78 & .56 & 3.50 & .53 & 3.81 & .64 & 3.87 & .71 & 3.89 & .62 & 3.60 & .73 \\
\hline Total & 3.89 & .57 & 3.36 & .45 & 3.71 & .61 & 3.49 & .46 & 3.82 & .60 & 3.88 & .59 & 3.87 & .55 & 3.51 & .65 \\
\hline \multicolumn{17}{|l|}{ School-type } \\
\hline Boys only & 3.86 & .54 & 3.30 & .42 & 3.61 & .64 & 3.48 & .47 & 3.78 & .61 & 3.89 & .59 & 3.87 & .53 & 3.49 & .61 \\
\hline Girls only & 3.93 & .56 & 3.42 & .43 & 3.78 & .58 & 3.49 & .40 & 3.86 & .56 & 3.86 & .56 & 3.88 & .55 & 3.50 & .66 \\
\hline Mixed & 3.88 & .60 & 3.37 & .49 & 3.74 & .61 & 3.50 & .51 & 3.85 & .63 & 3.90 & .63 & 3.87 & .56 & 3.54 & .68 \\
\hline Total & 3.89 & .57 & 3.36 & .45 & 3.71 & .61 & 3.49 & .46 & 3.82 & .60 & 3.88 & .59 & 3.87 & .55 & 3.51 & .65 \\
\hline
\end{tabular}

\subsection{Differences in the study skills strategies employed by senior high school science students across gender}

To test the hypothesis of no statistically significant differences in the study skills strategies employed by SHS science students in learning across gender, a one-way MANOVA was conducted. Pillai's Trace criterion was considered for the multivariate analysis because it's considered to be the most robust statistic against violations of assumptions (Field, 2006; Tabachnick \& Fidell, 2013). There was a statistically significant difference in mean scores between male together with female science students on the combined dependent variables $\left[F(1,598)=3.693, p<0.001\right.$, Pillai's Trace $=0.048, \eta^{2}=$ 0.048]. This means that about $5 \%$ of the multivariate variance of the eight dependent variables was associated with gender. A post-hoc power analysis also showed that at a critical $F(1,598)$, the observed power of the test $=0.987$, which means that the probability of finding a true significance as indicated in MANOVA is about $99 \%$. Hence, the assumption of no variation was overruled.

Since it became evident there was a statistically significant difference for the combined dependent variables, a follow-up univariate ANOVA tests was conducted to check the between-subject effects of the dependent variables on male and female science students. The results of the univariate ANOVA indicate that the only difference in mean scores to reach statistical significance was concentration $\left[F(1,598)=10.778, p=0.001, \eta^{2}=0.018\right.$, power $\left.=0.906\right]$. A review of the mean scores as represented in Table 3 indicates that the female students who offer science $(M=3.43, S D=0.46)$ employ memory and concentration as a study skills strategy than their male counterparts $(M=3.31, S D=0.44)$. On the other hand, the univariate ANOVA results indicate that there was no statistically significant difference in mean scores between male and female students for the study skill strategies: time management and procrastination $[F(1,598)=0.126, p=0.723]$, study aids and note-taking $[F(1,598)=1.931, p=$ $0.165]$, testing strategy and test anxiety $[F(1,598)=0.560, p=0.454]$, motivation and attitude $[F(1$, 
$598)=3.242, p=0.072]$, reading and selecting main ideas $[F(1,598)=0.203, p=0.653]$, organising and information processing $[F(1,598)=1.901, p=0.168]$ and writing skills $[F(1,598)=0.172, p=0.678]$.

It is no wonder that female science students use memory and concentration study skills strategy more often than males. This confirms the observations made by numerous studies (Bulent et al., 2015; Hagborg, 1991; Naqvi et al., 2018) that females have superior study habits as compared to males. Females, generally, make notes, pay attention, take instructions and spend more time on assignments and tasks during lectures and can store and recall information better (Bulent et al., 2015; Hagborg, 1991; Naqvi et al., 2018). This was elaborated more in a cross-sectional study by Al-Shawwa et al. (2014) who found out that $45.7 \%$ of females study between 3 and 4 hours a week as equated to their male counterparts (31.4\%).

\subsection{Differences in the study skills strategies employed by senior high school science students across school- type}

To test the hypothesis of no statistically significant differences in the study skills approaches adopted by SHS science learners across the three school-types-boys only, girls only and mixed-a one-way MANOVA was conducted. There was no statistically significant difference in mean scores among the three school types on the combined dependent variables $[F(2,597)=1.344, p=0.162$, Pillai's Trace $=0.036$ ]. The assumption of no significant difference was, hence, not overruled. This implies that students in all three school types employ the eight study skills strategies to the same level. Since every school type follows specific philosophy, mission, and vision and rules (Ebele \& Olofu, 2012), it was hoped that this could affect the way the students use study skills in learning, but the finding was contrary. It could be that schools in the study area used for this study follow similar ways of fostering learning.

\subsection{Differences in the study skills strategies employed by senior high school science students across age range}

To test the hypothesis of no statistically significant differences in the study skills approaches employed by SHS science learners across age range (i.e., 12-14, 15-17 and 18-20), one-way MANOVA was used. These age ranges were used because the lower and upper age ranges, 12 and 20, respectively, represent the typical minimum and maximum ages of students in SHS (Sarfo \& AnsongGyimah, 2011). No statistically significant difference was obtained as indicated by the age range $[F(2$, $597)=1.232, p=0.236$, Pillai's Trace $=0.033$ ]. It can be inferred that all science students in the age ranges used in this study employ the eight study skills strategies to some extent. This result contradicts the findings of Ebele and Olofu (2012) who posited that several factors including the age of the students affect study skills used by students in learning.

\section{Conclusion and recommendation}

Although this research was small-scale research limited to a single metropolis within Ghana, it provides some pertinent insights into the extent to which SHS science students use the eight subscales of study skills strategies in their learning. With regards to the results of this study, it can be established that SHS science students utilise the eight subscales of study skills (i.e., Time Management, and Procrastination; Concentration and Memory; Study Aids and Note-Taking; Test Strategies and Test Anxiety; Organizing and Processing Information; Motivation and Attitude; Reading and Selecting the Main Idea and Writing skills) to a high extent, female students employ the memory and concentration study skills strategy more effectively than their male counterparts, demographic variables, such as age range and school-type, do not influence students study skills significantly. 
It is recommended that additional variables that contribute positively to students' use of study skills in their learning should be investigated in further studies to determine their relative importance on students' performance. Further studies are needed to determine how the study skills strategies are integrated into the high school curriculum to foster learning. It is suggested that instructors should teach students how to utilise these study skills strategies in their studies.

\section{Acknowledgments}

The authors acknowledge the students who responded to their instruments and the authors whose materials they consulted.

\section{Conflict of interest}

The authors confirm that there is no conflict of interest with respect to the data presented in this paper.

\section{References}

Adeninyi, V. (2011). Studying to pass: implication for students. Lagos, Nigeria: Macmillan.

Al-Hilawani, Y. (2016a). Metacognition in real life situations and study skills and habits: Two types of processes. International Journal of Progressive Education, 12(1), 73-89

Alloway, T. P. \& Alloway, R. G. (2010). Investigating the predictive roles of working memory and IQ in academic attainment. Journal of Experimental Child Psychology, 106(1), 20-29. doi: 10.1016/j.jecp.2009.11.003

Al-Shawwa, L., Abulaban A. B., Algethami A., BaghJaf, S., Abushanab, J., Merdad, A. \& Abulaban, A. (2014). Differences in studying habits between male and female medical students of King Abdulaziz University. Egyptian Dental Journal, 60, 1687-1693.

Ashish, R. (2013). Study habits for students: bad ones to avoid, good ones to achieve success. Retrieved from www.education.wisc.education/soe/newsevents

Awang, M. G. \& Sinnadurai, S. K. (2011a). A study on the development of strategic tools in study orientation skills towards achieving academic excellence. Journal of Language Teaching \& Research, 2(1), 60-67. doi:10.4304/jltr.2.1.60-67

Baddeley, A. D. (2000). The episodic buffer: a new component of working memory? Trends Cognitive Science, 4 , 417-423. https://doi.org/10.1016/S1364-6613(00)01538-2

Bain, S. K., McCallum, R. S., Bell, S. M., Cochran, J. L. \& Sawyer, S. C. (2010). Foreign language learning aptitudes, attitudes, attributions, and achievement of postsecondary students identified as gifted. Journal of Advanced Academics, 22, 130-156. https://doi.org/10.1177/1932202X1002200106

Bandura, A. (1986). Social foundations of thought and action: a social cognitive theory. Englewood Cliffs, NJ: Prentice Hall.

Bashir, I. \& Mattoo, N.H. (2012). A study on study habits and academic performance of adolescents (14-19) years. International Journal of Social Science Tomorrow, 1(5), 131-152.

Bonaccio, S. \& Reeve, C. L. T. (2010). Nature and relative importance of students' perceptions of the sources of test anxiety. Learning and Individual Differences, 20, 617-625. https://doi.org/10.1016/i.lindif.2010.09.007

Block, C. \& Israel, S. (2005). Reading first and beyond: the complete guide for teachers and literacy coaches. Thousand Oaks, CA: Corwin Press.

Bremer, R. (2015). The manual: a guide to the ultimate study method (2nd ed.). Cambridge, UK: Fons Sapientiae Publishing.

Brown, G. T. (2010). The validity of examination essays in higher education: issues and responses. Higher Education Quarterly, 64(3), 276-291. https://doi.org/10.1111/i.1468-2273.2010.00460.x

Bulent, A., Hakan, K. \& Aydin, B. (2015). An analysis of undergraduates' study skills. Procedia-Social and Behavioural Sciences, 197, 1355-1362 doi:10.1016/i.sbspro.2015.07.389 
Aboagye, G. K., Amponsah, K. D. \& Johnson, E. A., (2020). Analysis of study skills employed by Ghanaian high school science students. Cypriot Journal of Educational Sciences. 15(4), 634 - 650. DOI: 10.18844/cjes.v\%vi\%i.5047

Capan, B. E. (2010). Relationship among perfectionism, academic procrastination and life satisfaction of university students. Procedia Social and Behavioural Sciences, 5, 1665-1671. doi:10.1016/i.sbspro.2010.07.342

Chapell, M. S., Blanding, Z. B. \& Silverstein, M. E. (2005). Test- anxiety and academic achievement in undergraduate and graduate students. Journal of Education Psychology, 97(2), 268-278.

Claessens, van Eerde, Rutte \& Roe, (2007). A review of time management literature. Web document. Retrieved May 27, 2019, from www.emeraldinsight.com/0048-3486.htm

Cogmen, S. \& Saracaloglu, A. S. (2009). Students' usage of reading strategies in the faculty of education. Procedia Social and behavioural Sciences, 1, 248-251. doi:10.1016/j.sbspro.2009.01.045

Cohen, L., Manion, L. \& Morrison, K. (2007). Research methods in education (6th ed.). London, UK: Routledge.

Cornick, J., Guy, G. M. \& Beckford, I. (2015). Integrating study skills and problem-solving into remedial mathematics. Teaching mathematics and its applications, 34(2), 83-90. doi:10.1093/teamat/hru028

Cottrell, S. (2005). Critical thinking skills: developing effective analysis and argument. New York: Palgrave Macmillan.

Cottrell, S. (2013). The study skills handbook (4th ed.). London, UK: Palgrave Macmillan.

Crede, M. \& Kuncel, N. R. (2008). Study habits, skills, and attitudes: The third pillar supporting collegiate academic performance. Perspectives on Psychological Science, 3(6), 425-453. doi:10.1111/i.17456924.2008.00089.x

Creswell, J. W. (2012). Educational research: planning, conducting, and evaluating quantitative and qualitative research (4th ed.). Boston, MA: Pearson.

Crow, A. (1968). Educational psychology: an outline with questions and answers. Totowa, NJ: A Littlefield, Adams \& Co.

Demir, S., Kilinc, M. \& Dogan, A. (2012). The effect of curriculum for developing efficient studying skills on academic achievements and studying skills of learners. International Electronic Journal of Elementary Education, 4(3), 427-440.

Dunlosky, J., Rawson, K. A., Marsh, E. J., Nathan, M. J. \& Willingham, D. T. (2013). Improving students' learning with effective learning techniques: promising directions from cognitive and educational psychology. Psychological Science in the Public Interest, 14(1), 4-58. https://doi.org/10.1177/1529100612453266

Ebele, U. F. \& Olofu, P. A. (2017). Study habit and its impact on secondary school students' academic performance in biology in the Federal Capital Territory, Abuja. Educational Research and Reviews, 12(10), $583-588$.

Entress, C. \& Wagner, A. (2014). Beyond hitting the books. Science Teacher, 81(4), 27-31.

Field, A. (2006). Discovering statistics using SPSS (2nd ed.). London, UK: Sage Publications.

Feuerstein, R., \& Falik, L. H. (2010). Learning to think, thinking to learn: A comparative analysis of three approaches to instruction. Journal of Cognitive Education and Psychology, 9(1), 4-20. doi:10.1891/19458959.9.1.4

Fougnie, D. (2008). The relationship between attention and working memory. In N. B. Johansen (Ed.), New research on short-term memory (pp. 1-45). Hauppauge, NY: Nova Science Publishers.

Gledhill, R. F. \& Van der Merwe, C. A. (1989). Gender as a factor in student learning: Preliminary findings. Medical Education, 23, 201-204. https://doi.org/10.1111/j.1365-2923.1989.tb00887.x

Grabe, M. (2005). Voluntary use of online lecture notes: correlates of note use and note use as alternative to class attendance. Computers \& Education, 44, 409-421. doi:10.1016/j.compedu.2004.04.005

Hagborg, W.J. (1991) A study of homework time of a high school sample. Perceptual and Motor Skills. 73, 103106. https://doi.org/10.2466/pms.1991.73.1.103

Haghverdi, H., R. R. Biria \& L. Karimi, 2010. The effect of note-taking strategy instruction on the students' academic achievement. The Journal of Asia TEFL, 7(2), 123-151.

Helfand, Z. (2017) Study reveals engineering majors spend significantly more time studying career choice, USA Today Collegehttp://college.usatoday.com/tag/college-living/, University of Michigan, CAMPUS LIFE, VOICES FROM CAMPUS, Retrieved from http://college.usatoday.com/2011/11/23/studyrevealsengineering-majors-spend-significantly-more-time-studying-2/. 17 July 2017. 
Aboagye, G. K., Amponsah, K. D. \& Johnson, E. A., (2020). Analysis of study skills employed by Ghanaian high school science students. Cypriot Journal of Educational Sciences. 15(4), 634 - 650. DOI: 10.18844/cjes.v\%vi\%i.5047

Hunsley, J. (1987). Cognitive processes in mathematics anxiety and test anxiety: the role of appraisals, internal dialogue, and attributions. Journal of Educational Psychology, 79(4), 388-392. https://doi.org/10.1037/0022-0663.79.4.388

Jani, J. S. \& Mellinger, M. S. (2015). Beyond "Writing to Learn": factors influencing students' writing outcomes. Journal of Social Work Education, 51(1), 136-152. https://doi.org/10.1080/10437797.2015.977177

Kern, M. L. \& Friedman, H. S. (2009). Early educational milestones as predictors of lifelong academic achievement, midlife adjustment, and longevity. Journal of Applied Developmental Psychology, 30, 419-430. https://doi.org/10.1016/j.appdev.2008.12.025

Kobayashi, K. (2005). What limits the encoding effect of note-taking? A meta-analytic examination. Contemporary Educational Psychology, 30(2), 242-262. https://doi.org/10.1016/j.cedpsych.2004.10.001

Knoch, U., May, L., Macqueen, S., Pill, J. \& Storch, N. (2016). Transitioning from university to the workplace: stakeholder perceptions of academic and professional writing demands. IELTS Research Reports Online Series, 37.

Komarraju, M. Karau, S. J. \& Schmeck, R. R. (2009). Role of the big five personality traits in predicting college students' academic motivation and achievement. Learning and Individual Differences, 19, 47-52.

Kose, N. (2006). Effects of portfolio implementation and assessment critical reading on learner autonomy of EFL students. Web document. Retrieved May 27, 2019, from http://www.belgeler.com/blg/12ta/effects-of-portfolio-implementation-and-assessment-on-criticalreading-and-learner-autonomy-of-elt-students

Kucukoglu, H. (2013). Improving reading skills through effective reading strategies Procedia-Social and Behavioral Sciences, 70, 709-714. doi:10.1016/j.sbspro.2013.01.113

Kumar, S., Kulkarni, P., Kavitha, H., \& Manjunath, R. (2016). Study skills and strategies of the medical students among the medical colleges in Mysore district, Karnataka, India. International Journal of Community Medicine and Public Health, 3(9), 2543-2549.

Maltepe, S. (2016). Critical thinking dispositions of pre-service Turkish language teachers and primary teachers. Journal of Education and Training Studies, 4(6), 44-50. https://doi.org/10.11114/jets.v4i6.1353

Meneghetti, C., Carretti, B., \& De Beni, R. (2006). Components of reading comprehension and scholastic achievement. Learning and Individual Differences, 16, 291-301. https://doi.org/10.1016/j.lindif.2006.11.001

Mizuno, K., Tanaka, M., Ishii, A., Tanabe, H. C., Onoe, H., Sadato, N. \& Watanabe, Y. (2008). The neural basis of academic achievement motivation. Neurolmage, 42, 369-378. https://doi.org/10.1016/i.neuroimage.2008.04.253

NAEP (2011). Writing framework learn how the NAEP writing assessment is designed to measure students' writing at grades 4, 8, and 12. Web document. Retrieved May 27, 2019, from http://www.nagb.org/publications/frameworks/writing-2011.pdf

Nagaraju, M. T. (2004). Study habits of secondary school students. New Delhi, India: Discovery Publishing House.

Naqvi, S., Chikwa, G., Menon, U. \& Al Kharusi, D. (2108). Study skills assessment among undergraduate students at a Private University College in Oman. Mediterranean Institute of Statistical, Social and Economic Research (2015). ISSER annual report 2015-2016. Accra: University of Ghana Journal of Social Sciences, 9(2), 139-147.

Ncube, T. R. \& Zondo R. W. D. (2018). Influence of self-motivation and intrinsic motivational factors for small and medium business growth: a South African case study. South African Journal of Economic and Management Sciences, 21(1), 1-7. http://dx.doi.org/10.4102/sajems.v21i1.1994

Ogbodo, R. O. (2010). Effective study habits in educational sector: counselling implications. Edo Journal of Counselling, 3(1), 1-11. DOI: 10.4314/ejc.v3i2.63610

Osah-Edoh, G. I. \& Aluta A. N. G. (2012). A Survey of students' study habits in secondary schools: implication for counselling. Current Research Journal of Social Sciences, 4(3), 228-234.

Ozsoy, G., Memis, A. \& Temur, T. (2009). Metacognition, study habits and attitudes. International Electronic Journal of Elementary Education, 2(1), 154-166. Retrieved from https://iejee.com/index.php/IEJEE/article/view/263 
Aboagye, G. K., Amponsah, K. D. \& Johnson, E. A., (2020). Analysis of study skills employed by Ghanaian high school science students. Cypriot Journal of Educational Sciences. 15(4), 634 - 650. DOI: 10.18844/cjes.v\%vi\%i.5047

Papa, E. M., Castro, J. L., Emralino, J., Rey, M., Baygan, A. V. M. \& Baccay, A. B. (2016). Study habits and skills of freshman students in Polytechnic University of the Philippines Paranaque City Campus: an assessment. European Academic Research, 4(8), 2605-2642.

Parks-Stamm, E. J., Gollwitzer, P. M. \& Oettingen, G. (2007). Action control by implementation intentions: effective cue detection and efficient response initiation. Social Cognition, 25, 247-264. https://doi.org/10.1521/soco.2007.25.2.248

Putwain, D., Sander, P. \& Larkin, D. (2013). Academic self-efficacy in study-related skills and behaviours: relations with learning-related emotions and academic success. British Journal of Educational Psychology, 83(4), 633-650. doi:10.1111/j.2044-8279.2012.02084.x

Renzulli, S. J. (2015). Using learning strategies to improve the academic performance of university students on academic probation. NACADA Journal, 35(1), 29-41. https://doi.org/10.12930/NACADA-13-043

Rozendaal, J. S., Minnaert, A. \& Boekaerts, M. (2003). Motivation and self-regulated learning in secondary vocational education: information-processing type and gender differences. Learning and Individual Differences, 13, 273-289. doi: 10.1016/S1041-6080(03)00016-5

Sarfo, F. K. \& Ansong-Gyimah, K. (2011). Ghanaian senior high school students' access to and experiences in the use of information and communication technology. Education In the technological world: Communicating Current and Emerging Research and Technological Efforts, 216-222.

Sekar, J. A. \& Rajendran, K. K. (2015). Study skills of Arts and Science Students. Indian e-Journal on Teacher Education, 3(2), 6-55.

Shetty, S. S. \& Srinivasan, S. R. (2014). Effectiveness of study skills on academic performance of dental students. Journal of Education and Ethics in Dentistry, 4(1), 28-31.

Slotte, V. \& Lonka, K. (1999). Review and process effects of spontaneous notetaking on text comprehension. Contemporary Educational Psychology, 24, 1-20. https://doi.org/10.1006/ceps.1998.0980

Smith, J., Groves, M., Bowd, B. \& Barber, A. (2012). Facilitating the development of study skills through blended learning approach. International Journal of Higher Education, 1(2), 108-

117.

Steel, P. (2007). The nature of procrastination: a meta-analytic and theoretical review of quintessential self-regulatory failure. Psychological Bulletin, 133, 65-94. https://doi.org/10.1037/0033-2909.133.1.65

Tabachnick, B. G., \& Fidell, L. S. (2013). Using multivariate statistics (6th ed.). Boston, MA: Pearson.

Thorpe, C. (2010). Promoting academic achievement in the middle school classroom: integrating effective study skills instruction. Online Submission. Retrieved June 2, 2019, from http://www.eric.ed.gov

Van Eerde, W. (2003). Procrastination at work and time management training. The Journal of Psychology Interdisciplinary and Applied, 137(5), 421-434. doi:10.1080/00223980309600625.

Vermunt, J. D. \& Verloop, N. (2000). Dissonance in students' regulation of learning processes. European Journal of Psychology of Education, 15, 75-89.

Yadav, V. S., Ansari, M. R. \& Savant P. A. (2000). A critical analysis of study habits and academic achievement of college students. A Journal of Agricultural Sciences, 13(4), 914-918. 